Recebido em: 04/06/2021. Aprovado em: 22/07/2021. Publicado em: 20/08/2021

Processo de Avaliação: Double Blind Review - SEER/OJS

e-ISSN: 2359-5876

https://doi.org/10.48075/comsus.v8i1.27522

\title{
Derivatives or climate insurance? Risk management tools for a soybean farmer in Brazil
}

\section{Derivativos ou seguro climático? Ferramentas de gerenciamento de risco para o produtor de soja no Brasil}

\section{ABSTRACT}

Fernanda Bortoluzzi Lorenzetti ${ }^{1}$

Edison Luiz Leismann ${ }^{2}$

Claudio Antonio Rojo ${ }^{3}$

This paper aims to analyze whether there is a difference between the cost/benefit of climate risk reduction and cost/benefit of soybean price in Palotina, Paraná, Brazil. The data were collected from bibliography, official and private documents. Climate data were analyzed based on the releases content. The methodology to analyze de future market data was the same as the B3. Options were analyzed as Black \& Scholes model. Also, this paper developed the Leismann \& Bortoluzzi index to analyze the protections cost/benefit. To compare mitigation costs, there were used the $t$ student test. Limitations were about the Black \& Scholes model, which does not consider subjective variables. Cost/benefit index of price protections were compared with the climate insurance index in order to test if there was a statistical difference between them. All tests allowed to infer that the indices are statistically different. This study concluded that climate and price insurance are excellent tools for rural enterprise risk management, and there was significant evidence to infer that the protections are feasible. Or rather, that the farmer is exposed to both types of risk and that the forms of mitigation are satisfactory in both cases.

Key-words: Sustainability; Risk Management; Climate Insurance; Future Market; Option Market.

\section{RESUMO}

O presente trabalho possui como objetivo analisar se existe diferença entre o custo/benefício de mitigação de risco climático e de preço na comercialização de soja no município de Palotina-PR. A coleta de dados ocorreu junto à órgãos governamentais e privados. A metodologia utilizada para análise dos dados de mercado futuro foi a utilizada pela B3. Os preços justos de opções foram calculados com base na metodologia de Black \& Scholes. Ainda, desenvolveu-se o índice Leismann \& Bortoluzzi para análise do custo/benefício das proteções. Por fim, utilizou-se o teste estatístico tstudent para comparar médias. As limitações do estudo dizem respeito ao modelo Black \& Scholes que não considera variáveis subjetivas. O custo de mitigação de preço foi comparado com o custo de mitigação climático e todos os testes apontaram resultados que permitiram inferir que os índices são estatisticamente diferentes. Conclui-se então que o seguro climático e o seguro de preço são excelentes ferramentas para gerenciamento de risco da empresa rural, e houve evidências significativas para inferir que as proteções são viáveis. Ou melhor, o agricultor está exposto aos dois tipos de risco e as formas de mitigação são satisfatórias em ambos os casos.

Palavras-chave: Sustentabilidade; Gerenciamento de Risco; Seguro Climático; Mercado Futuro; Mercado de Opções.

Cite as: (APA) Lorenzetti, F. B., Leismann, E. L., \& Rojo, C. A. (2021). Derivatives or climate insurance? Risk management tools for a soybean farmer in Brazil. Revista Competitividade e Sustentabilidade, 8(1), 72-87.

\footnotetext{
1 Universidade Estadual do Oeste do Paraná - UNIOESTE. Brasil. E-mail: lorenzettifb@gmail.com

2 Universidade Estadual do Oeste do Paraná - UNIOESTE. Brasil. E-mail: elleismann@hotmail.com

3 Universidade Estadual do Oeste do Paraná - UNIOESTE. Brasil. E-mail: rojo 1970@hotmail.com
} 
Lorenzetti, F. B., Leismann, E. L., \& Rojo, C. A. (2021). Derivatives or climate insurance? Risk management tools for a soybean farmer in Brazil. Revista Competitividade e Sustentabilidade

\section{INTRODUCTION}

Over the last 20 to 30 years, there was a consistent increase in soybean producing areas (Thoenes, 2017). This is due to the need to feed the world's growing population. Proving this growth, the estimate for the $2018 / 2019$ oilseed crop is 359.49 million tons, $6.76 \%$ above the previous crop (United States Department of Agricultural, 2019). Brazilian soybean production has grown by $20 \%$ in the last 10 years, according to Brazilian National Supply Company (2019), making the country one of the three largest soybean producers in the world, alongside the United States and Argentina.

Given the growth and the global and national importance of this activity, it is necessary to understand the risks the farmer is exposed to and the ways to reduce, if not eliminate. Risk is the probability of occurrence of something unwanted. In other words, it is associated with the uncertainty that affects the individual's well-being (Harwood et al., 1999). Uncertainties about climate, diseases, technology, government policies, exchange rate and commodity price fluctuations and the perishable nature of the product are examples of what the farmer has to deal with (Beierlein et al., 2013).

An effective way to control risks is to use insurance. Insurance is a way of transferring risk between parties (Ozaki, 2005). In other words, according to Rothschild \& Stiglitz (1976), and Arrow (1971), through the payment of a premium the insured agent receives compensation in the case of an unwanted event. Still, in the case of agricultural insurance, the role of prevention is to reduce the probability of risk or even prevent the occurrence of adverse events (Birovljev et al., 2015).

Two types of insurance will be dealt in this paper: climate insurance and price fluctuation. Climate insurance is a way to protect against climate adversity. In Brazil, there is a government incentive for farmers to access this protection, Programa de Garantia da Atividade Agropecuária. A derivative is a financial instrument in which the price is derived from an underlying instrument for the purpose of speculation and/or, mainly, protection (Fortuna, 2015), in this case against price fluctuations. Having a clear understanding about risks and how much risk they face may help them to manage risk in an efficient way (Capitani \& Mattos, 2017).

Derivatives market as a mean of protection for the soybean farmer has been discussed for some time, but it is still embryonic in Brazil. Won Mühlen et al. (2013) have identified the use of the derivatives market in the country is still low, this is due to the lack of knowledge of producers, as well as the absence of reliable professionals to guide them. On the same line, Rodrigues \& Cunha (2013) and Cardelli \& Souza (2011) emphasize that derivative is an important tool for minimizing risks. Therefore, this paper aims to analyze whether there is a difference between the cost/benefit of climate risk reduction and cost/benefit of soybean price in Palotina, Paraná, Brazil.

\section{MATERIALS AND METHODS}

The weather data were collected from SIMEPAR - Meteorological System of Paraná -, within the Palotina area, and included 22 years, from 1997 to 2018. Soybean price and production were collected on DERAL - Parana Rural Economy Department -, and CONAB Brazilian National Supply Company - considering the same area and the same time period as above. At last, derivative data were collected from B3 - Brazilian Stock Exchange - including the soybean season -6 months, for 22 years.

The rainfall data were analyzed considering periods of greater and lesser water 
Lorenzetti, F. B., Leismann, E. L., \& Rojo, C. A. (2021). Derivatives or climate insurance? Risk management tools for a soybean farmer in Brazil. Revista Competitividade e Sustentabilidade

requirement of the grain, in order to identify the necessity of request agricultural insurance. The analysis was daily covering the period of plant development and especially in the stage of grain filling, which according to Souza et al. (2013) is the phase that the plant most needs water (7-8mm/day). It is also worth noting that the amount of water required varies according to the soybean cycle time, climatic conditions and crop management (Farias et al., 2007; EMBRAPA, 2013). Sowing date was on September $15^{\text {th }}$, which means that the grain filling period is on November $19^{\text {th }}$ to December $29^{\text {th }}$. During this period, there was necessary a great amount of rain, however the following period until the harvest, there was no need to rain. The insurance cost against the climate risk divided by the risk gives the cost benefit of the protection.

There are two types of derivatives that were studied in this paper, Hedge and Options. Each one has some specifications and costs. The first one requires warranty margin of $4.32 \%$ of the contract value, transaction costs, and income tax. The warranty margin is an amount needed to cover the daily adjustments. Transaction costs are about $0.64 \%$ of contract value, and the income tax is $15 \%$ of financial gain. If there is no gain, there is no income tax. It is highlighted that warranty margin and daily adjustments have to be net values in a brokerage account. Therefore, if the farmer does not have the amount, there will be an extra cost, the cost of loan money. In this case, we applied Selic interest for each year during the borrowing period.

Option Contracts require a premium, transaction costs, and income tax. The premium depends on the commodity future price, the strike price, the risk-free rate, time, and volatility. There were no data to collect on option premium, therefore, in order to have a fair put option premium, we decided to apply the Black \& Scholes model (1973), which, according to Lei (1992) is the first completely satisfactory model for option price analysis. The model equation is following.

$$
\begin{gathered}
P=X e^{-r t} \times N\left(-d_{2}\right)-S_{o} e^{-t} \times N\left(-d_{1}\right) \\
d_{1}=\frac{\ln \left(\frac{S_{o}}{X}\right)+t\left(r+\frac{\sigma^{2}}{2}\right)}{\sigma \sqrt{t}} \\
d_{2}=d_{1}-\sigma \sqrt{t}
\end{gathered}
$$

Where:

$P=$ Put option price;

$\mathrm{N}(\mathrm{x})=$ Standard normal cumulative distribution function;

So $=$ Underlying price (per contract);

$\mathrm{X}=$ Strike price;

$\sigma=$ Volatility (\% per year);

$r=$ Risk-free interest rate (Selic); and,

$t=$ Time to expiration.

The put option price is a value the farmer pay for the right to sell a soybean sack in a future date for a pre-set price. An Option Contract has 450 sacks, which means the farmer has to buy, at least, this amount of put options. All the data needed for the formula were collected from B3, except the volatility. Volatility is the dimensioning through statistical calculation of how much the prices oscillate around the average during a certain period (Schouchana \& 
Lorenzetti, F. B., Leismann, E. L., \& Rojo, C. A. (2021). Derivatives or climate insurance? Risk management tools for a soybean farmer in Brazil. Revista Competitividade e Sustentabilidade

Miceli, 2004) and it was calculated using the equation below.

$$
\sigma_{\text {annual }}=\left(\sqrt{\sum_{t=1}^{n} \frac{\left(\ln \left(\frac{P_{t}}{P_{t-1}}\right)\right)-\mu}{n-1}}\right) * \sqrt{\text { working days }}
$$

Where:

$\mu=$ Arithmetic mean;

$\sigma=$ Standard deviation;

$\mathrm{P}_{\mathrm{t}}=$ Current price;

$\mathrm{P}_{\mathrm{t}-1}=$ Preceding period price; and,

In = natural logarithm.

At last, in order to perceive de cost/benefit, we developed an index based on Sortino (1994) about semivariance, or downside risk, which only considers variances that may represent financial losses. That is, it is assumed the really important risk for the farmer is the one which represents financial loss. This index was named Leismann \& Bortoluzzi Index (LB) and it is calculated using the following equation.

$$
L B=\frac{\overline{C M}}{\sqrt{\frac{\sum M i n\left(x_{i}-\bar{x} ; 0\right)^{2}}{n-1}}}
$$

Which:

$\mathrm{CM}=$ protection average cost, in percentual;

$\mathrm{x}_{\mathrm{i}} \quad=$ risk, in percentual;

$\overline{\mathrm{x}} \quad=$ average risk, in percentual;

$\mathrm{n} \quad=$ total number of observations.

Specifically, the numerator represents the average cost of protection in the period. The denominator represents the total risk of the sample. When the difference between the risk and the average risk is greater than zero (a positive value), it is automatically assumed that there was no risk and the value is converted to zero.

\section{RESULTS AND DISCUSSION}

First of all, the results were divided in three sections. In the first part, we analyzed the climate data and insurance, then the price data and the hedge contracts, and, finally, the price data and the option contracts.

The rainfall data show the amount of rain in a certain period. According to Souza et al. (2013), soybeans need 7 to 8 millimeters/day of rain during the plant's development period and, especially, at the grain filling stage - for this particular case the period between November $19^{\text {th }}$ and December $29^{\text {th }}$. The low level of rainfall implies in a low productivity that is why Brazilian government has implemented the Proagro program. This program supports the 
Lorenzetti, F. B., Leismann, E. L., \& Rojo, C. A. (2021). Derivatives or climate insurance? Risk management tools for a soybean farmer in Brazil. Revista Competitividade e Sustentabilidade

farmer when the recorded productivity is lower than $60 \%$ of the expected productivity (Law 8.171 , January $\left.17^{\text {th }}, 1991\right)$. The rainfall average and the productivity are shown in Table 01.

Table 01 Rainfall average and productivity in Palotina - PR

\begin{tabular}{|c|c|c|c|c|c|}
\hline $\begin{array}{l}\text { Soybean } \\
\text { crop }\end{array}$ & $\begin{array}{l}\text { Rainfall (mm/day) } \\
\text { Grain Filling Stage }\end{array}$ & $\begin{array}{c}\text { Expected } \\
\text { Productivity } \\
\text { (sacks/hectare) }\end{array}$ & $\begin{array}{c}\text { Recorded } \\
\text { Productivity } \\
\text { (sacks/hectare) }\end{array}$ & $\begin{array}{c}\text { Risk }^{1} \\
\text { (sacks/hectare) }\end{array}$ & $\begin{array}{l}\text { PROAGRO } \\
\text { application }\end{array}$ \\
\hline $1997 / 98$ & 4.90 & 50 & 37.17 & 0.00 & No \\
\hline 1998/99 & 3.52 & 50 & 53.33 & 0.00 & No \\
\hline 1999/00 & 3.88 & 50 & 40.00 & 0.00 & No \\
\hline $2000 / 01$ & 4.17 & 50 & 53.33 & 0.00 & No \\
\hline $2001 / 02$ & 3.00 & 50 & 58.33 & 0.00 & No \\
\hline $2002 / 03$ & 2.93 & 50 & 50.00 & 0.00 & No \\
\hline $2003 / 04$ & 7.97 & 50 & 36.67 & 0.00 & No \\
\hline $2004 / 05$ & 2.45 & 50 & 51.67 & 0.00 & No \\
\hline $2005 / 06$ & 3.38 & 50 & 33.05 & 0.00 & No \\
\hline 2006/07 & 5.39 & 50 & 51.67 & 0.00 & No \\
\hline $2007 / 08$ & 3.81 & 50 & 50.00 & 0.00 & No \\
\hline 2008/09 & 1.22 & 50 & 21.67 & $-56.66 \%$ & Yes \\
\hline $2009 / 10$ & 8.99 & 50 & 63.33 & 0.00 & No \\
\hline $2010 / 11$ & 9.69 & 50 & 57.83 & 0.00 & No \\
\hline $2011 / 12$ & 1.11 & 50 & 22.00 & $-56.00 \%$ & Yes \\
\hline $2012 / 13$ & 6.29 & 50 & 58.33 & 0.00 & No \\
\hline $2013 / 14$ & 4.56 & 50 & 56.67 & 0.00 & No \\
\hline $2014 / 15$ & 2.80 & 50 & 55.00 & 0.00 & No \\
\hline $2015 / 16$ & 21.24 & 50 & 60.00 & 0.00 & No \\
\hline 2016/17 & 4.73 & 55 & 68.33 & 0.00 & No \\
\hline $2017 / 18$ & 8.69 & 55 & 60.00 & 0.00 & No \\
\hline Minimum & 1.11 & 50 & 21.67 & & \\
\hline Maximum & 21.24 & 55 & 68.33 & & \\
\hline Average & 5.46 & 50.48 & 49.45 & & \\
\hline Std deviation & 4.35 & 1.50 & 12.89 & & \\
\hline
\end{tabular}

Note $^{1}$ : the calculation of the risk in percentage was made using the formula: ((average productivity - expected productivity)/average productivity) $\times 100$. If the result was greater than -60.00 it was converted to 0 (zero), except in two cases. Source: Elaborated by authors (2020) from SIMEPAR and DERAL data.

Table 01 also shows the Proagro application. Whereas the recorded productivity is an average, we have decided to infer from the data that when the value is about $60 \%$, Proagro was needed. It means Proagro was needed in 2008/09 (-56.55\%) and in 2011/12 (-56.00\%). However, there is a cost to benefit from the government program. This cost has to be paid by the farmer and the rate is $4.5 \%$ of the contract value. To make the following analysis clear and, considering that a future contract consists at least 450 sacks, the cost was calculated based on 9 hectares ( 450 sacks multiplied by 50.48 - expected productivity average). To make it even clear, the cost was brought to present value, as shown in Table 02. 
Lorenzetti, F. B., Leismann, E. L., \& Rojo, C. A. (2021). Derivatives or climate insurance? Risk management tools for a soybean farmer in Brazil. Revista Competitividade e Sustentabilidade

Table 02. Climate protection cost

\begin{tabular}{|c|c|c|c|}
\hline $\begin{array}{l}\text { Soybean } \\
\text { crop }\end{array}$ & $\begin{array}{l}\text { Financial cost (09 ha) } \\
\text { (presente value) }\end{array}$ & $\begin{array}{l}\text { Proagro cost } \\
\text { rate }\end{array}$ & $\begin{array}{c}\text { Total Proagro cost } \\
\text { (present value) }\end{array}$ \\
\hline $1997 / 98$ & $\mathrm{R} \$ 16.015,50$ & $4,5 \%$ & $\mathrm{R} \$ 720,70$ \\
\hline 1998/99 & $\mathrm{R} \$ 15.795,00$ & $4,5 \%$ & $\mathrm{R} \$ 710,78$ \\
\hline 1999/00 & $\mathrm{R} \$ 17.523,00$ & $4,5 \%$ & $\mathrm{R} \$ 788,54$ \\
\hline $2000 / 01$ & $\mathrm{R} \$ 17.788,50$ & $4,5 \%$ & $\mathrm{R} \$ 800,48$ \\
\hline $2001 / 02$ & $\mathrm{R} \$ 17.748,00$ & $4,5 \%$ & $\mathrm{R} \$ 798,66$ \\
\hline $2002 / 03$ & $\mathrm{R} \$ 19.278,00$ & $4,5 \%$ & $\mathrm{R} \$ 867,51$ \\
\hline $2003 / 04$ & $\mathrm{R} \$ 23.170,50$ & $4,5 \%$ & $\mathrm{R} \$ 1.042,67$ \\
\hline $2004 / 05$ & $\mathrm{R} \$ 32.868,00$ & $4,5 \%$ & $\mathrm{R} \$ 1.479,06$ \\
\hline $2005 / 06$ & $R \$ 28.008,00$ & $4,5 \%$ & $\mathrm{R} \$ 1.260,36$ \\
\hline 2006/07 & $R \$ 26.743,50$ & $4,5 \%$ & $\mathrm{R} \$ 1.203,46$ \\
\hline $2007 / 08$ & $R \$ 24.570,00$ & $4,5 \%$ & $\mathrm{R} \$ 1.105,65$ \\
\hline $2008 / 09$ & $R \$ 26.815,50$ & $4,5 \%$ & $\mathrm{R} \$ 1.206,70$ \\
\hline $2009 / 10$ & $\mathrm{R} \$ 31.711,50$ & $4,5 \%$ & $\mathrm{R} \$ 1.427,02$ \\
\hline $2010 / 11$ & $\mathrm{R} \$ 27.310,50$ & $4,5 \%$ & $\mathrm{R} \$ 1.228,97$ \\
\hline $2011 / 12$ & $R \$ 25.569,00$ & $4,5 \%$ & $\mathrm{R} \$ 1.150,61$ \\
\hline $2012 / 13$ & $\mathrm{R} \$ 26.064,00$ & $4,5 \%$ & $\mathrm{R} \$ 1.172,88$ \\
\hline $2013 / 14$ & $R \$ 28.876,50$ & $4,5 \%$ & $\mathrm{R} \$ 1.299,44$ \\
\hline $2014 / 15$ & $\mathrm{R} \$ 29.272,50$ & $4,5 \%$ & $\mathrm{R} \$ 1.317,26$ \\
\hline $2015 / 16$ & $R \$ 29.281,50$ & $4,5 \%$ & $\mathrm{R} \$ 1.317,67$ \\
\hline $2016 / 17$ & $R \$ 30.163,50$ & $4,5 \%$ & $\mathrm{R} \$ 1.357,36$ \\
\hline $2017 / 18$ & $R \$ 27.688,50$ & $4,5 \%$ & $\mathrm{R} \$ 1.245,98$ \\
\hline Minimum & $\mathrm{R} \$ 15.795,00$ & & $\mathrm{R} \$ 710,78$ \\
\hline Maximum & $R \$ 32.868,00$ & & $\mathrm{R} \$ 1.479,06$ \\
\hline Average & $\mathrm{R} \$ 24.869,57$ & & $\mathrm{R} \$ 1.119,13$ \\
\hline Std deviation & $R \$ 5.368,90$ & & $\mathrm{R} \$ 241,60$ \\
\hline
\end{tabular}

Source: Elaborated by authors (2020) from SEAB/DERAL data.

Knowing the cost of climate protection (Proagro) and the estimated risk of production reduction, it is possible to calculate the cost/benefit of this kind of insurance. Here, we applied the Leismann \& Bortoluzzi Index (LB). The LB interpretation was based on Von NeumannMorgenstern's Theorem (1944) that assumes preferences based on a cardinal indexer. In other words, and as said by Baumol (1958), suppose there is a 3 yards long table and it needs to be completely covered by two pieces of fabric. In this case, 3 yards works as an index. Thus, the indexer has been established in a way that makes it possible to combine the objects without measuring the two pieces.

Based on the aforementioned, the indexer fixed was 1, that is, if $L B<1$, the cost/benefit protection is feasible; if $L B>1$, the cost/benefit of the protection is unfeasible. Even more valuable, it is to emphasize that the index is only a marker and the decision to contract the insurance, even in cases of unfeasibility, depends uniquely on the farmer's risk profile.

That said, LB equation was applied as following. 
Lorenzetti, F. B., Leismann, E. L., \& Rojo, C. A. (2021). Derivatives or climate insurance? Risk management tools for a soybean farmer in Brazil. Revista Competitividade e Sustentabilidade

$$
\begin{gathered}
L B_{\text {climate insurance } w / \text { aid }}=\frac{\overline{C M}}{\sqrt{\frac{\sum M i n\left(x_{i}-\bar{x} ; 0\right)^{2}}{n-1}}} \quad \frac{0,045}{\sqrt{\frac{0,6061}{21-1}}} \quad \frac{0,045}{\sqrt{0,03031}} \quad \frac{0,045}{0,1741} \\
\boldsymbol{L B}_{\text {climate insurance } \mathbf{w} / \text { aid }}=\mathbf{0 , 2 5 8 5}
\end{gathered}
$$

Proagro has a government aid about $35 \%$ of the premium value. Whereas Proagro rate is $4.5 \%$ with aid, if there was no aid, it would be $35 \%$ higher, that is $6.92 \%$. In this case, there is a higher LB Index, as following.

$$
\begin{aligned}
& L B_{\text {climate insurance no aid }}=\frac{\overline{C M}}{\sqrt{\frac{\sum \operatorname{Min}\left(x_{i}-\bar{x} ; 0\right)^{2}}{n-1}}} \quad \frac{0,0692}{\sqrt{\frac{0,6061}{21-1}}} \quad \frac{0,0692}{\sqrt{0,3031}} \quad \frac{0,0692}{0,174083313} \\
& L B_{\text {climate insurance no aid }}=0,3975
\end{aligned}
$$

LB Index without aid is slightly higher, however it is still feasible from the LB point of view. Therefore, at this point it can be inferred that climate insurance with or without aid are feasible for mitigation in terms of cost/benefit, although we cannot infer if this insurance is better than the others. For that, the second and third parts of the study are necessary.

The second part of the study was to analyze hedge contracts for soybean production. Hedge is a position that have the purpose of reducing or eliminating part of the risk (Gastineau \& Kritzman, 1996). The main function of this market is to protect against price fluctuations (Fortuna, 2015). Hull (1996) points out that the main objective when seeking these types of contracts is to neutralize the risk involved.

The data were collected during about 6 months (September $15^{\text {th }}$ to April $30^{\text {th }}$ ) in the period of 1997 to 2018. At this point, we came up with the hedge contract cost and risk to understand the of cost/benefit, as shown in Table 03. An important observation is that some years are missing because the data was not available on B3 website. 
Lorenzetti, F. B., Leismann, E. L., \& Rojo, C. A. (2021). Derivatives or climate insurance? Risk management tools for a soybean farmer in Brazil. Revista Competitividade e Sustentabilidade

Table 03. Hedge contracts, mitigation cost and risk

\begin{tabular}{cccc}
\hline Soybean Crop & Mitigation Cost & Risk $^{\mathbf{1}}$ & Volatility \\
\hline $1997 / 98$ & $0.65 \%$ & 0.00 & $0.943 \%$ \\
$1998 / 99$ & $0.72 \%$ & 0.00 & $1.007 \%$ \\
$1999 / 00$ & $1.39 \%$ & $5.1465 \%$ & $0.731 \%$ \\
$2000 / 01$ & $0.67 \%$ & 0.00 & $0.670 \%$ \\
$2006 / 07$ & $0.66 \%$ & 0.00 & $0.892 \%$ \\
$2007 / 08$ & $0.69 \%$ & 0.00 & $1.553 \%$ \\
$2008 / 09$ & $0.65 \%$ & 0.00 & $2.312 \%$ \\
$2011 / 12$ & $0.68 \%$ & 0.00 & $1.032 \%$ \\
$2012 / 13$ & $1.88 \%$ & $8.6544 \%$ & $1.072 \%$ \\
$2013 / 14$ & $0.66 \%$ & 0.00 & $0.947 \%$ \\
$2014 / 15$ & $0.69 \%$ & 0.00 & $1.335 \%$ \\
$2015 / 16$ & $0.63 \%$ & 0.00 & $0.947 \%$ \\
$2016 / 17$ & $1.58 \%$ & $6.5426 \%$ & $0.994 \%$ \\
$2017 / 18$ & $0.67 \%$ & 0.00 & $0.865 \%$ \\
\hline
\end{tabular}

Note $^{1}$ : There is no risk when the contract is not effective, and the soybean price goes up. Source: Elaborated by authors (2020).

Mitigation cost presented above is assuming a self-funding, that is, the farmer has enough money to pay the fees and the warranty margin. The warranty margin represents $4.32 \%$ of the total amount of the contract and it is necessary to cover the price variation, in order to secure the transaction. In addition, as shown in Table 03, there is a significant difference on mitigation cost when the protection is effective, this is due to the income tax $15 \%$ of the profit.

All data being presented, the LB Index for self-funding hedge contracts is calculated as following.

$$
\begin{aligned}
& L B_{\text {self-funding hedge }}=\frac{\overline{C M}}{\sqrt{\frac{\sum M i n\left(x_{i}-0 ; 0\right)^{2}}{n-1}}} \quad \frac{0,0087}{\sqrt{\frac{0,014419}{14-1}}} \quad \frac{0,0087}{\sqrt{0,001109}} \quad \frac{0,0087}{0,03330} \\
& L B_{\text {self-funding hedge }}=0,2613
\end{aligned}
$$

The LB Index is lower than 1, which means the cost/benefit of self-funding hedge is feasible. In other words, if the farmer has available money, the hedge is a practicable alternative.

In a second moment, we assumed the farmer has no available money to self-funding. In this case, loan costs were incorporated to transaction costs. The loan costs were based on Selic rate for each year, and it was applied to the amount of warranty margin $(4.32 \%)$, considering that it is the amount the farmer need to pay for the insurance. The results are shown on Table 04, and in the sequence, the LB Index calculation. 
Lorenzetti, F. B., Leismann, E. L., \& Rojo, C. A. (2021). Derivatives or climate insurance? Risk management tools for a soybean farmer in Brazil. Revista Competitividade e Sustentabilidade

Table 04. Hedge contracts, mitigation cost, financial cost and risk

\begin{tabular}{ccccc}
\hline Soybean crop & Mitigation cost & Financial cost & Total cost & Risk $^{\mathbf{1}}$ \\
\hline $1997 / 98$ & $0,65 \%$ & $1,02 \%$ & $1,67 \%$ & $0,00 \%$ \\
$1998 / 99$ & $0,72 \%$ & $0,76 \%$ & $1,48 \%$ & $0,00 \%$ \\
$1999 / 00$ & $1,39 \%$ & $0,50 \%$ & $1,89 \%$ & $5,1465 \%$ \\
$2000 / 01$ & $0,67 \%$ & $0,42 \%$ & $1,09 \%$ & $0,00 \%$ \\
$2006 / 07$ & $0,66 \%$ & $0,33 \%$ & $0,99 \%$ & $0,00 \%$ \\
$2007 / 08$ & $0,69 \%$ & $0,28 \%$ & $0,97 \%$ & $0,00 \%$ \\
$2008 / 09$ & $0,65 \%$ & $0,34 \%$ & $0,99 \%$ & $0,00 \%$ \\
$2011 / 12$ & $0,68 \%$ & $0,29 \%$ & $2,07 \%$ & $0,00 \%$ \\
$2012 / 13$ & $1,88 \%$ & $0,19 \%$ & $0,92 \%$ & $8,6544 \%$ \\
$2013 / 14$ & $0,66 \%$ & $0,26 \%$ & $1,00 \%$ & $0,00 \%$ \\
$2014 / 15$ & $0,69 \%$ & $0,31 \%$ & $1,00 \%$ & $0,00 \%$ \\
$2015 / 16$ & $0,63 \%$ & $0,37 \%$ & $1,94 \%$ & $0,00 \%$ \\
$2016 / 17$ & $1,58 \%$ & $0,36 \%$ & $0,84 \%$ & $6,5426 \%$ \\
$2017 / 18$ & $0,67 \%$ & $0,17 \%$ & $0,00 \%$ \\
\hline
\end{tabular}

Note $^{1}$ : There is no risk when the contract is not effective, and the soybean price goes up. Source: Elaborated by authors (2020).

$$
L B_{\text {funded hedge }}=\frac{\overline{C M}}{\sqrt{\frac{\sum \operatorname{Min}\left(x_{i}-0 ; 0\right)^{2}}{n-1}}} \quad \frac{0,0127}{\sqrt{\frac{0,014419}{14-1}}} \quad \frac{0,0127}{\sqrt{0,001109}} \quad \frac{0,0127}{0,03330}
$$

$$
L B_{\text {funded hedge }}=0,3813
$$

LB Index funded is lower than 1 , that is it is feasible. Still, it is a slightly higher than the self-funding hedge this is due to the cost increase when we incorporated the loan cost to the mitigation cost.

At this point, we can infer that the hedge contract is effective based o its cost/benefit analysis. Both are lesser than 1 , that is even if the loan is needed and the cost increases, the contract is feasible.

Another way of protection against price fluctuation is the option contract. This contract is an instrument in the derivatives market that allows the farmer, in an unfavorable scenario, to have a fixed price; and, in a favorable scenario, to take advantage of the profits (Fortuna, 2015).

Options allow the transfer of the risk of the price fluctuation between the parties (Schouchana \& Miceli, 2004). Ries (2000) points out that options consist in the right to take a long or short position for a certain price at a certain future date. Also, when purchasing an option, one of the parties protects itself against unfavorable price changes to its position and, on the other hand, benefits in case of a favorable change.

The soybean producer has a product to sell at a future date, so it is needed to protect the sales. With this in mind, the farmer has to purchase a put option. A put option is the right, but not the duty, to sell an asset or a commodity for a certain exercise price until the maturity date of the contract (Gastineau \& Kritzman, 1996; BMF\&Bovespa/CVM, 2015).

A crucial information about the options is the premium. The option premium is paid to the other party through a brokerage firm, and it is considered a cost to the farmer. In addition, it is an amount disbursed by the farmer and that is not reimbursed under any circumstances. On the expiration date, the producer has the right to execute his option or not, it always 
Lorenzetti, F. B., Leismann, E. L., \& Rojo, C. A. (2021). Derivatives or climate insurance? Risk management tools for a soybean farmer in Brazil. Revista Competitividade e Sustentabilidade

depends on the soybean price.

Furthermore, in accordance with the methodology, the Black \& Scholes model was used to calculate the fair premium of the options, since there was no information available on the Brazilian Stock Exchange. Table 05 shows the premium values calculated through de model.

Table 05. Option premium calculated through the Black \& Scholes model

\begin{tabular}{ccc}
\hline Soybean crop & Put option premium value (R\$) & Total contract premium option (R\$) \\
\hline $1998 / 99$ & $\mathrm{R} \$ 0,2071$ & $\mathrm{R} \$ 93,20$ \\
$1999 / 00$ & $\mathrm{R} \$ 0,9512$ & $\mathrm{R} \$ 428,04$ \\
$2000 / 01$ & $\mathrm{R} \$ 0,7373$ & $\mathrm{R} \$ 331,79$ \\
$2006 / 07$ & $\mathrm{R} \$ 2,4845$ & $\mathrm{R} \$ 1.118,03$ \\
$2007 / 08$ & $\mathrm{R} \$ 3,3979$ & $\mathrm{R} \$ 1.529,06$ \\
$2008 / 09$ & $\mathrm{R} \$ 5,7631$ & $\mathrm{R} \$ 2.593,40$ \\
$2011 / 12$ & $\mathrm{R} \$ 5,2688$ & $\mathrm{R} \$ 2.370,96$ \\
$2012 / 13$ & $\mathrm{R} \$ 0,2540$ & $\mathrm{R} \$ 114,30$ \\
$2013 / 14$ & $\mathrm{R} \$ 1,6006$ & $\mathrm{R} \$ 720,27$ \\
$2014 / 15$ & $\mathrm{R} \$ 1,6732$ & $\mathrm{R} \$ 752,94$ \\
$2015 / 16$ & $\mathrm{R} \$ 4,3328$ & $\mathrm{R} \$ 1.949,76$ \\
$2016 / 17$ & $\mathrm{R} \$ 2,5732$ & $\mathrm{R} \$ 1.157,94$ \\
$2017 / 18$ & $\mathrm{R} \$ 7,1831$ & $\mathrm{R} \$ 3.232,40$ \\
\hline
\end{tabular}

Source: Elaborated by authors (2020).

As we have already standardized the size of the contract, we multiplied the put option premium to 450 sacks, then we had the total contract premium the farmer has to purchase in order to protect the production. This was considered a cost, since it is a disbursement. Therefore, the mitigation cost is presented as a percentual of the total contract and includes all the contract fees and also the premium option. Risk, as in other cases, was calculated based on the effectiveness of the contract. In other words, there is risk when there is lost, and the insurance is applied. Table 06 shows the results for the option contracts.

Table 06. Option mitigation cost, risk and volatility

\begin{tabular}{cccc}
\hline Soybean Crop & Mitigation Cost & Risk $^{\mathbf{1}}$ & Volatility \\
\hline $1998 / 99$ & $4.68 \%$ & $16.66 \%$ & $1.007 \%$ \\
$1999 / 00$ & $5.34 \%$ & $1.36 \%$ & $0.731 \%$ \\
$2000 / 01$ & $6.04 \%$ & $11.96 \%$ & $0.670 \%$ \\
$2006 / 07$ & $8.85 \%$ & 0.00 & $0.892 \%$ \\
$2007 / 08$ & $8.98 \%$ & 0.00 & $1.553 \%$ \\
$2008 / 09$ & $14.03 \%$ & $10.16 \%$ & $2.312 \%$ \\
$2011 / 12$ & $10.29 \%$ & 0.00 & $1.032 \%$ \\
$2012 / 13$ & $1.57 \%$ & $7.11 \%$ & $1.072 \%$ \\
$2013 / 14$ & $2.55 \%$ & 0.00 & $0.947 \%$ \\
$2014 / 15$ & $3.78 \%$ & $2.82 \%$ & $1.335 \%$ \\
$2015 / 16$ & $5.75 \%$ & 0.00 & $0.947 \%$ \\
$2016 / 17$ & $4.02 \%$ & $1.85 \%$ & $0.994 \%$ \\
$2017 / 18$ & $10.54 \%$ & 0.00 & $0.865 \%$ \\
\hline
\end{tabular}

Note $^{1}$ : There is no risk when the contract is not effective, and the soybean price goes up. Source: Elaborated by authors (2020). 
Lorenzetti, F. B., Leismann, E. L., \& Rojo, C. A. (2021). Derivatives or climate insurance? Risk management tools for a soybean farmer in Brazil. Revista Competitividade e Sustentabilidade

There was assumed in Table 06 that the farmer has enough money to self-funding. Applying the LB index, we have the following result.

$$
L B_{\text {self-funding options }}=\frac{\overline{C M}}{\sqrt{\frac{\sum \operatorname{Min}\left(x_{i}-0 ; 0\right)^{2}}{n-1}}} \quad \frac{0,0665}{\sqrt{\frac{0,05876}{13-1}}} \quad \frac{0,0665}{\sqrt{0,004897}} \quad \frac{0,0665}{0,06998}
$$

$$
L B_{\text {self-funding options }}=0,9503
$$

Interpreting the LB Index, the use of self-funding options is considered a viable choice, since it is lesser than 1 . Although it is near than 1 , it must be still considered feasible.

Subsequently, we have incorporated the loan cost considering the farmer was not able to self-funding. The loan costs were based on Selic, as in the hedge section and it was applied to the amount of mitigation cost in each year, considering that it is the amount the farmer need to pay for the insurance. Table 07 shows the incorporated costs and the risk. Soon after, the result of the Leismann \& Bortoluzzi Index on case of funding.

Table 07. Option contracts, mitigation cost, financial cost and risk

\begin{tabular}{ccccc}
\hline Soybean crop & Mitigation cost (\%) & Financial cost (\%) & Total cost (\%) & Risk (\%) \\
\hline $1998 / 99$ & $4,68 \%$ & $0,82 \%$ & $5,50 \%$ & $16,66 \%$ \\
$1999 / 00$ & $5,34 \%$ & $0,62 \%$ & $5,96 \%$ & $1,36 \%$ \\
$2000 / 01$ & $6,04 \%$ & $0,58 \%$ & $6,62 \%$ & $11,96 \%$ \\
$2006 / 07$ & $8,85 \%$ & $0,68 \%$ & $9,53 \%$ & 0,00 \\
$2007 / 08$ & $8,98 \%$ & $0,58 \%$ & $9,56 \%$ & 0,00 \\
$2008 / 09$ & $14,03 \%$ & $1,11 \%$ & $15,14 \%$ & $10,16 \%$ \\
$2011 / 12$ & $10,29 \%$ & $0,69 \%$ & $10,98 \%$ & 0,00 \\
$2012 / 13$ & $1,57 \%$ & $0,07 \%$ & $1,64 \%$ & $7,11 \%$ \\
$2013 / 14$ & $2,55 \%$ & $0,16 \%$ & $2,71 \%$ & 0,00 \\
$2014 / 15$ & $3,78 \%$ & $0,27 \%$ & $4,05 \%$ & $2,82 \%$ \\
$2015 / 16$ & $5,75 \%$ & $0,50 \%$ & $6,25 \%$ & 0,00 \\
$2016 / 17$ & $4,02 \%$ & $0,33 \%$ & $4,35 \%$ & $1,85 \%$ \\
$2017 / 18$ & $10,54 \%$ & $0,42 \%$ & $10,96 \%$ & 0,00
\end{tabular}

Source: Elaborated by authors (2020).

$$
L B_{\text {funded options }}=\frac{\overline{C M}}{\sqrt{\frac{\sum \operatorname{Min}\left(x_{i}-0 ; 0\right)^{2}}{n-1}}} \quad \frac{0,0717}{\sqrt{\frac{0,05876}{12}}} \quad \frac{0,0717}{\sqrt{0,004897}} \quad \frac{0,0717}{0,06998}
$$

$$
L B_{\text {funded options }}=1,0246
$$

It should be noted that the index, when there is a need for funding, is higher than in self-funding case. This is due to the incorporation of financial costs, which generates an increase in total costs. This additional cost makes the protection unfeasible from the LB point of view, as the result is higher than 1. In this particular case, it is strongly recommended knowing the risk aversion profile of the farmer. It means, if the farmer is a higher risk aversion, 
Lorenzetti, F. B., Leismann, E. L., \& Rojo, C. A. (2021). Derivatives or climate insurance? Risk management tools for a soybean farmer in Brazil. Revista Competitividade e Sustentabilidade

the decision could be purchasing the insurance even if it is unfeasible.

Al last, we applied statistical tests to see if there is a significant difference between the results found previously. Eight tests were carried out, the first four using government aid for climate insurance, and the last four using no government aid for climate insurance. All the results are shown on Table 08.

Table 08. Statistical tests and results

\begin{tabular}{|c|c|c|c|}
\hline Test & Hypothesis & P-Value & Result \\
\hline LB climate insurance $\mathrm{w} /$ aid $\mathrm{X}$ & $\mathrm{H}_{0}=\mathrm{m}_{1}=\mathrm{m}_{2}(0,2585=0,2613)$ & & \\
\hline LB self-funded hedge & $H_{1}=m_{1} \neq m_{2}(0,2585 \neq 0,2613)$ & 0,01569382 & $H_{1}=0,2585 \neq 0,2613$ \\
\hline LB climate insurance $\mathrm{w} /$ aid $\mathrm{X}$ & $\mathrm{H}_{0}=\mathrm{m}_{1}=\mathrm{m}_{2}(0,2585=0,3813)$ & & \\
\hline LB funded hedge & $\mathrm{H}_{1}=\mathrm{m}_{1} \neq \mathrm{m}_{2}(0,2585 \neq 0,3813)$ & 0,04304629 & $\mathrm{H}_{1}=0,2585 \neq 0,3813$ \\
\hline LB climate insurance $\mathrm{w} /$ aid $\mathrm{X}$ & $H_{0}=m_{1}=m_{2}(0,2585=0,9503)$ & & \\
\hline LB self-funding options & $H_{1}=m_{1} \neq m_{2}(0,2585 \neq 0,9503)$ & 0,005390768 & $\mathrm{H}_{1}=0,2585 \neq 0,9503$ \\
\hline LB climate insurance $w /$ aid $X$ & $H_{0}=m_{1}=m_{2}(0,2585=1,0246)$ & & \\
\hline LB funded options & $H_{1}=m_{1} \neq m_{2}(0,2585 \neq 1,0246)$ & 0,008553305 & $H_{1}=0,2585 \neq 1,0246$ \\
\hline LB climate insurance no aid $X$ & $H_{0}=m_{1}=m_{2}(0,3975=0,2613)$ & & \\
\hline LB self-funding hedge & $\mathrm{H}_{1}=\mathrm{m}_{1} \neq \mathrm{m}_{2}(0,3975 \neq 0,2613)$ & 0,01413416 & $H_{1}=0,3975 \neq 0,2613$ \\
\hline LB climate insurance no aid $X$ & $\mathrm{H}_{0}=\mathrm{m}_{1}=\mathrm{m}_{2}(0,3975=0,3813)$ & & \\
\hline LB funded hedge & $H_{1}=m_{1} \neq m_{2}(0,3975 \neq 0,3813)$ & 0,04098514 & $H_{1}=0,3975 \neq 0,3813$ \\
\hline LB climate insurance no aid $X$ & $\mathrm{H}_{0}=\mathrm{m}_{1}=\mathrm{m}_{2}(0,3975=0,9503)$ & & \\
\hline LB self-funding options & $H_{1}=m_{1} \neq m_{2}(0,3975 \neq 0,9503)$ & 0,005193848 & $\mathrm{H}_{1}=0,3975 \neq 0,9503$ \\
\hline LB climate insurance no aid $X$ & $\mathrm{H}_{0}=\mathrm{m}_{1}=\mathrm{m}_{2}(0,3975=1,0246)$ & & \\
\hline LB funded options & $\mathrm{H}_{1}=\mathrm{m}_{1} \neq \mathrm{m}_{2}(0,3975 \neq 1,0246)$ & 0,008446723 & $H_{1}=0,3975 \neq 1,0246$ \\
\hline
\end{tabular}

Source: Elaborated by authors (2020).

The significance level set for the tests was 0.05. All hypotheses tests performed in this study returned a $\mathrm{p}$-value lower than the established significance level. It means that the $\mathrm{H}_{0}$ hypothesis must be refuted and the $\mathrm{H}_{1}$ hypothesis is automatically accepted. Thus, allowing us to infer that there is a significant difference in the combinations tested above.

Therefore, we concluded that in the last 21 years, on average, the farmer should mitigate both types of risk. For that, we presented in this study three important tools: climate insurance, hedge and options. The first one is a protection against climate events and the last two are protections against price fluctuation. This is the most important contribution from the study, to introduce some efficient tools for an effective risk management.

In order to clarify the decision-making process, we have prepared a simplified chart flow (Figure 01) to the process. A relevant concern is about negative Profit Margin (PM), which could be a prerogative for non-mitigation of risks. However, the farmer should pay attention to the fact that if the future price was static and PM negative, the best decision would be do not plant soybean seeds. Even in this situation, the farmer decides to plant the seeds and this 
Lorenzetti, F. B., Leismann, E. L., \& Rojo, C. A. (2021). Derivatives or climate insurance? Risk management tools for a soybean farmer in Brazil. Revista Competitividade e Sustentabilidade

is due to two main points: (1) soybean future price may change until the harvest day, and (2) farm has fixed costs, such as: depreciation, land opportunity cost, employees, and so on. Taking these points into account, to plant is preferable even with negative Profit Margin.

Figure 01. Decision-making process chart flow

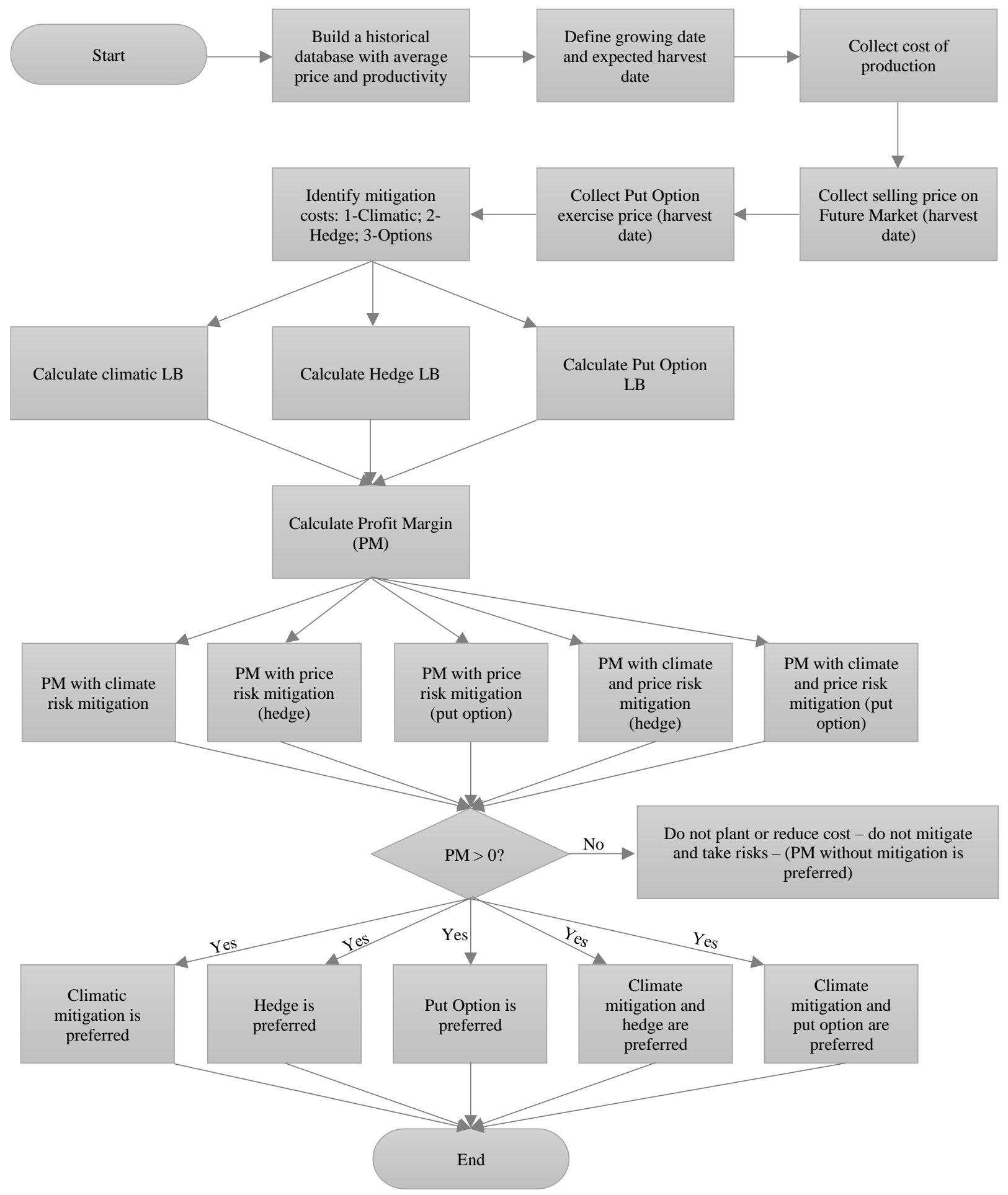

Source: Elaborated by authors (2020). 
Lorenzetti, F. B., Leismann, E. L., \& Rojo, C. A. (2021). Derivatives or climate insurance? Risk management tools for a soybean farmer in Brazil. Revista Competitividade e Sustentabilidade

\section{CONCLUSION}

A good management of the rural enterprise includes full knowledge of the activity and the ways to mitigate, whenever possible, all the possible losses. The farmer must be responsible for managing and having a full vision of the business, it means seek as much information as possible.

That said, this paper sought to analyze if there was a difference between the cost/benefit of climate risk mitigation and the price fluctuation mitigation of soybean in Palotina-PR. For this purpose, we analyze the climate and price data available from 1997 to 2018.

Climate data allowed us to infer that in $9.52 \%$ of the years analyzed, the climate insurance was triggered. Hedge contracts were needed in $21.43 \%$, and option contracts were used in $53.85 \%$ of the cases. Regards to LB Index, it is possible to infer that either the climate insurance or price fluctuation insurance are effective alternatives for the farmer. Except the funded option that returned a value higher than 1 . Anyway, as already said, it wholly depends on farmer risk aversion. Hypotheses allow us to infer that the indexes are different. That is, when there is no government aid, the self-funded hedge is the most effective alternative for the farmer.

Therefore, this paper becomes even more relevant to the farmer, since, in most cases producers seek tools for climate protection and does not observe that the greatest risk is linked to soybean price fluctuation.

There is a limitation in this study related to the expected profitability. Mitigating only one, the other, or both risks can greatly reduce the profit of the farmer. In some cases, mitigation may even cost the entire profit. This assessment would allow the farmer to decide more assertively taking into account the risk aversion profile and the financial need in the period.

Finally, in order to advance in the field of study and contribute to both academy and practice, it is recommended: (a) analyze the future contracts available on Chicago Board of Trade (СВОT) for the Brazilian farmer; (b) apply structures transactions using both future and foreign exchange contracts; and, (c) develop a study on a possible income insurance for the farmer, which takes into account the climate losses, the price fluctuation losses, and also assures a percentage of income.

\section{REFERENCES}

Arrow, K. J. (1971). Essays in the theory of risk bearing. Chicago: North-Holland Publishing Company.

Beierlein, J. G., Schneeberger, K. C., \& Osburn, D. D. (2013). Principles of Agribusiness Management ( 5 ed.). Long Grove, IL: Waveland Press, Inc.

Birovljev, J., Vojinovic, Z., \& Balaban, M. (2015). Potential of agricultural production and its impact on insurance premiums. Economics of Agriculture, 62(3), 705-722. doi: 10.5937/ekoPolj1503705B.

Black, F., \& Scholes, M. (1973). The Pricing of Options and Corporate Liabilities. The Journal of Political Economy, 81(3), 637-654. Available at <http://www.jstor.org/stable/1831029>. 
Lorenzetti, F. B., Leismann, E. L., \& Rojo, C. A. (2021). Derivatives or climate insurance? Risk management tools for a soybean farmer in Brazil. Revista Competitividade e Sustentabilidade

BM\&FBovespa, Comissão de Valores Mobiliários - CVM. (2015). Mercado de Derivativos no Brasil: conceitos, produtor e operações. Rio de Janeiro: BMF\&Bovespa - CVM.

Brasil. Lei $\mathrm{n}$ o 8.171, de 17 de janeiro de 1991. Dispõe sobre a política agrícola. Diário Oficial da União, Brasília, DF, 17 jan. 1991.

Capitani, D. H. D. \& Mattos, F. Measurement of Commodity Price Risk: an overview of Brazilian agricultura markets. Rev. Econ. Sociol. Rural, 55(3), 515-532. doi: https://doi.org/10.1590/1234-56781806-94790550306.

Cardelli, C. E., \& Souza, W. A. R. (2011). Comparative analysis of the hedging effectiveness for soybean using ols and bivatiate Garch Bekk Model. Revista de Economia, 37(3), 2146. doi: http://dx.doi.org/10.5380/re.v37i3.27533.

Companhia Nacional de Abastecimento. (2019). Observatório Agrícola: acompanhamento da safra brasileira grãos, 6(5).

Empresa Brasileira de Pesquisa Agropecuária. (2011). Sistemas de Produção 16. Available at <https://ainfo.cnptia.embrapa.br/digital/bitstream/item/95489/1/SP-16-online.pdf>.

Farias, J. R. B., Nepomuceno, A. L., \& Neumaier, N. (2007). Ecofisiologia da soja. Circular Técnica 48. Embrapa: Londrina, PR. Available at <https://www.infoteca.cnptia.embrapa.br/infoteca/handle/doc/470308>.

Fortuna, E. (2015). Mercado Financeiro: produtos e serviços. (20 ed.). Rio de Janeiro: Qualitymark Editora.

Gastineau, G. L. \& Kritzman, M. P. (1996). Dictionary of Financial Risk Management. New Hope, PA: Frank J. Fabozzi Assoc.

Harwood, J., Heifner, R., Coble, K., Perry, J., \& Somwary, A. (1999). Managing risk in Farming: Concepts, Research, and Analysis. Economic Research Service. Agricultural Economic Report No. 774. Washington: USDA.

Hull, J. (1996). Introdução aos Mercados Futuros e de Opções. (2 ed.). São Paulo: Cultura Editores Associados.

Kairalla, J. C. (2015). Avaliação do risco e o impacto do hedge simultâneo de preços e câmbio para o exportador de café no Brasil (Dissertação, ESALQ-USP, 2015). Available at <http://www.teses.usp.br/teses/disponiveis/11/11132/tde-14122015-092754/>.

Lei, L. F. (1992). Using futures and options contracts to manage price and quantity risk: a case of corn farmers in central lowa. (Tese, lowa State University, 1992). doi: https://doi.org/10.31274/rtd-180813-9653.

Ozaki, V. A. (2005). Métodos atuariais aplicados à determinação da taxa de prêmio de contratos de seguro agrícola: um estudo de caso. (Tese, ESALQ-USP, 2005). doi: 10.11606/T.11.2005.tde-11072005-160540.

Ries, L. R. (2000). Comercialização Agropecuária: mercado futuro e de opções. Guaíba: Agropecuária.

Rodrigues, G. Z., \& Cunha, C. A. (2013). Operações de hedge de milho para importantes municípios goianos. Revista de Política Agrícola, 22(4), 38-55. 
Lorenzetti, F. B., Leismann, E. L., \& Rojo, C. A. (2021). Derivatives or climate insurance? Risk management tools for a soybean farmer in Brazil. Revista Competitividade e Sustentabilidade

Rothschild, M., \& Stiglitz, J. (1976). Equilibrium in competitive insurance markets: an essay on the economics of imperfect information. Quarterly Journal of Economics, 90(4), 629-649.

Schouchana, F. \& Miceli, W. M. (2004). Introdução aos mercados futuros e opções agropecuários no Brasil. (3 ed.). São Paulo: Bolsa de Mercadorias \& Futuros. doi: https://doi.org/10.3905/joi.3.3.59.

Souza, G.M., Catuchi, T.A., Bertolli, S.C., Soratto, R. (2013). Soybean under water deficit: physiological and yield responses. In: J. E. Board (ed.), A comprehensive survey of international soybean research - Genetics, physiology, agronomy and nitrogen relationships. Intech: Rijeka.

Souza, W. A. R. (2010). Gestão estratégica da produção de soja em Mato Grosso com o uso dos mercados futuros e opções (Tese, USP, 2010). doi: 10.11606/T.11.2010.tde14122010-081715.

Souza, W. A. R., Martinez-Filho, J. G., \& Marques, P. V. (2011). O hedge simultâneo dos riscos de preço e de câmbio da produção de soja em Rondonópolis (MT), utilizando contratos da Bovespa-BM\&F. Organizações Rurais \& Agroindustriais, 13(3), 403-413. doi: 10.22004/ag.econ.134186.

Souza, W. A. R., Martinez-Filho, J. G., \& Marques, P. V. (2012). Análise de estratégias de hedge simultâneo para a produção de soja no Centro-Oeste. Revista de Economia, 38(2), 73-92. doi: http://dx.doi.org/10.5380/re.v38i2.29903.

Thoenes, P. (2017). Soybean International Commodity Profile. Available at <http://siteresources.worldbank.org/INTAFRICA/Resources/2579941215457178567/Soybean Profile.pdf>

United States Department of Agricultural. (2019). World Agricultural Supply and Demand Estimates. Available at <https://www.usda.gov/oce/commodity/wasde/wasde1219.pdf>.

Won Mühlen, A. S. R., Cezar, I. M., \& Costa, F. P. (2013). Risco de preço na comercialização da soja: uso de derivativos pelos produtores rurais de Maracaju-MS. Ciência Rural, 43(5), 937-943. doi: https://doi.org/10.1590/S0103-84782013005000031. 